Artur KUREK

AWF Kraków

\title{
MOŻLIWOŚCI WYKORZYSTANIA METOD ANDRAGOGIKI W KRAJOZNAWSTWIE TURYSTYCZNYM
}

\section{Wprowadzenie}

Celem artykułu jest próba przeniesienia doświadczeń związanych z kształceniem i wychowaniem osób dorosłych na grunt krajoznawstwa turystycznego. Wskazano również możliwości wprowadzenia niektórych zasad andragogiki do procesu poznawczego realizowanego $\mathrm{w}$ trakcie turystyki krajoznawczej. Określono wytyczne, będące wskazówkami do umiejętnego zaadaptowania do krajoznawstwa turystycznego metod kształcenia dorosłych. Dzięki temu możliwe będzie uatrakcyjnienie krajoznawstwa turystycznego w grupie osób dorosłych.

\section{Znaczenie andragogiki}

Zdaniem Turosa, jednym z najstarszych i najgłębszych pragnień człowieka jest potrzeba poznawania otaczającego świata. By zaspokoić te pragnienia ludzie podróżują, wędrują nieustannie zmieniają miejsce stałego pobytu. Osoby dorosłe często potwierdzają, że turystyka staje się dla nich źródłem radości życia, uszczęśliwia ich. Dzięki niej dostrzegają piękno, różnorodność i niezwykłość otaczającej ich rzeczywistości. Poznawanie atrakcji krajoznawczych dla wielu dorosłych wiąże się z doskonaleniem własnej osobowości, a także utwierdza w poczuciu sensu istnienia. Niewątpliwie andragogika turystyki jest potwierdzeniem, iż uprawianie przez ludzi dorosłych turystyki, w szczególności krajoznawczej, w sposób racjonalny, wartościowy oraz rozwijający osobowość wymaga właściwego przygotowania. Dlatego też powstanie oraz rozwój andragogiki 
turystyki wiąże się przede wszystkim z koniecznością badania, poznawania i wyjaśniania możliwości uprawiania turystyki, która zaspokaja różne, np. zdrowotne, rekreacyjne czy kulturoznawcze potrzeby dorosłych, a także uczy umiejętności szybkiego przystosowania się do zmieniającej się sytuacji (Turos, 2004).

W andragogice turystyki zwraca się uwagę na fakt, że do uprawiania turystyki wartościowej pod każdym względem - rozwijającej osobowość dorosłych, dającej zadowolenie i poczucie sensu życia - niezbędne jest rozumienie jej jako wartości humanistycznej. Każdy dorosły, pojmując w ten sposób znaczenie turystyki, zdaje sobie sprawę, jak ważną rolę odgrywa jego zaangażowanie w przygotowanie do mądrego uczestnictwa w tym procesie. Badanie rzeczywistych zachowań turystów w sytuacjach zetknięcia $\mathrm{z}$ atrakcyjnymi obiektami przyrodniczymi lub kulturowymi, czyli podczas uprawiania turystyki krajoznawczej, umożliwia andragogice turystyki ustalenie norm optymalnego i efektywnego postępowania turystycznego. Andragogika turystyki bada cele, metody, warunki oraz skutki przygotowania dorosłych do rozumnego, emocjonalnego uprawiania turystyki, a także utrwalania jej wyników, np. w formie fotografii lub filmu (Zaorska, Kędzior-Niczyporuk, 2000).

Przedmiotem badań omawianej subdyscypliny andragogicznej jest proces uczenia turystów rozwiązywania problemów, które związane są z rozumnym, świadomym, i co ważne, ukierunkowanym na wartości humanistyczne uprawianiem turystyki. Problemy te wiążą się choćby z podjęciem decyzji o uczestnictwie w wycieczce krajowej lub zagranicznej, wyborem trasy turystycznej, przyswojeniem wiedzy o zwiedzanym miejscu oraz przygotowaniem rzeczy niezbędnych do podróżowania i spędzania czasu wolnego. Subdyscyplina ta bada nie tylko typowe, powszechne i najczęstsze zachowania dorosłych, lecz przedmiotem swoich poszukiwań czyni te formy aktywności turystów, które są wyrazem nowoczesnego, przyszłościowego, a także skutecznego rozwiązywania problemów wynikłych w trakcie i na skutek zwiedzania lub podróżowania. Celem andragogiki jest odpowiedź na pytanie o sposób tworzenia takich warunków podróżowania i zwiedzania różnych obiektów krajoznawczych, by możliwa była harmonijna zgodność celów określonych przez grupę i akceptowanych przez wszystkich uczestników programu danej wyprawy. Istotne jest $\mathrm{w}$ tej sytuacji uwzględnienie indywidualnych potrzeb dorosłych, ich aspiracji, zainteresowań oraz zamiłowań (Kaczor, 2001).

Turystyka krajoznawcza bez wątpienia w sposób znaczący jest w stanie wspomóc aktywność poznawczą dorosłych. Może również okazać 
się ważnym czynnikiem wpływającym na zwiększenie jakości pracy dydaktyczno-wychowawczej. Dzieje się tak, ponieważ ta aktywność wytwarza i wzmacnia u dorosłych zdolność do obserwacji oraz działalności twórczej. Podczas aktywności turystycznej dochodzi do integracji nauczania i wychowania. Siłą napędową turystyki staje się zainteresowanie dorosłych otaczającym światem, innymi ludźmi oraz ich dokonaniami i sposobem na życie oraz rozrywkę. Ta niezaspokojona ciekawość świata staje się źródłem turystyki (Meyer, 2006).

Istota współczesnego ruchu turystycznego dorosłych osób tkwi w ucieczce w czasie wolnym od codzienności i pracy zawodowej na łono przyrody, w celu regeneracji sił psycho-fizycznych. W edukacji dorosłych mamy do czynienia także z zajęciami krajoznawczo-turystycznymi. Związane jest to z realizacją przez dorosłych indywidualnych pragnień odpoczynku i poznania własnego kraju zarówno w aspekcie przeszłości, jak również teraźniejszości i przyszłości. Dla każdego z nas poznanie ojczystego kraju to wartość nadrzędna, a ruch krajoznawczo-poznawczy stanowi środek do osiągnięcia tego celu (Wujek, 2006).

Przecławski pisze, iż badania zachowania ludzi dorosłych $\mathrm{w}$ trakcie wyjazdów turystycznych mogą pomóc w lepszym zrozumieniu systemu wartości tych osób oraz ich stylu życia. W całokształcie współczesnej turystyki podróżowanie osób dorosłych zajmuje szczególne miejsce. Mimo że jednostka dorosła posiada mniej czasu wolnego, np. z powodu wykonywanej pracy bądź obowiązków rodzinnych, jej potrzeba uprawiania różnych form turystyki jest tak silna, iż staje się istotnym elementem życia tej osoby. Dlatego też zadanie andragogiki turystyki sprowadza się często np. do analizowania zmian zachodzących w sposobie uprawiania turystyki przez dorosłych, motywacji skłaniających ich do wyjazdu, zachowania w trakcie wyjazdu i podczas zwiedzania (Przecławski, 1996).

\section{Model właściwego zachowania przewodnika i pilota wycieczek krajoznawczych}

Rola przewodnika turystycznego i pilota wycieczek zmienia się nieustannie z biegiem czasu. Zmiany te są wynikiem współczesnej turystyki krajoznawczej, która stawia przed przewodnikiem czy pilotem nowe zadania, wymagające wszechstronnej wiedzy o bieżących wydarzeniach politycznych, kulturalnych oraz społecznych w kraju i za granicą. W andragogice rola i funkcje przewodnika oraz pilota wycieczek są podobne, często pokrywają się ze sobą i wzajemnie się uzupełniają. 
Jak pisze Meyer, za realizację danej imprezy turystycznej główną odpowiedzialność ponosi pilot wycieczki. Musi on sumiennie wykonywać obowiązki na nim spoczywające, które wiążą się ze sferą opiekuńczą, handlową i obywatelską osób dorosłych (Meyer, 2006).

Obowiązki opiekuńcze polegają na stwarzaniu turystom możliwości beztroskiego spędzania czasu $\mathrm{w}$ trakcie trwania imprezy turystycznej. Osoby dorosłe biorące w niej udział muszą mieć świadomość, że w momencie zaistnienia problemów mogą polegać na odpowiedzialnej i kompetentnej osobie, która służy pomocą i wsparciem. Do obowiązków opiekuńczych pilota, dających turystom poczucie bezpieczeństwa, należy zaliczyć: ciągłą dyspozycyjność, udzielanie informacji i pomocy, pełnienie funkcji tłumacza i animatora oraz realizowanie wszystkich punktów programu (Kruczek, 2014).

Obowiązki obywatelskie pilota to dbałość o dobre imię ojczystego kraju. Pilot powinien dbać, aby uczestnicy imprezy turystycznej właściwie się zachowywali i godnie reprezentowali swój kraj. Wiąże się to z umiejętnością respektowania przez turystów zwyczajów i kultury odwiedzanych krajów, szacunkiem do tradycji i symboli narodowych oraz tolerancją dla innych religii i poglądów politycznych (Gołembski, 2003).

Pełnienie funkcji pilota wycieczek lub przewodnika wymaga umiejętności współpracy z ludźmi bez względu na ich wiek, wykształcenie i status społeczny. Przewodnicy oraz piloci wycieczek powinni odznaczać się kompetencją znajomością zasad komunikacji interpersonalnej oraz określonymi cechami osobowości (Meyer, 2006) (rys. 1).

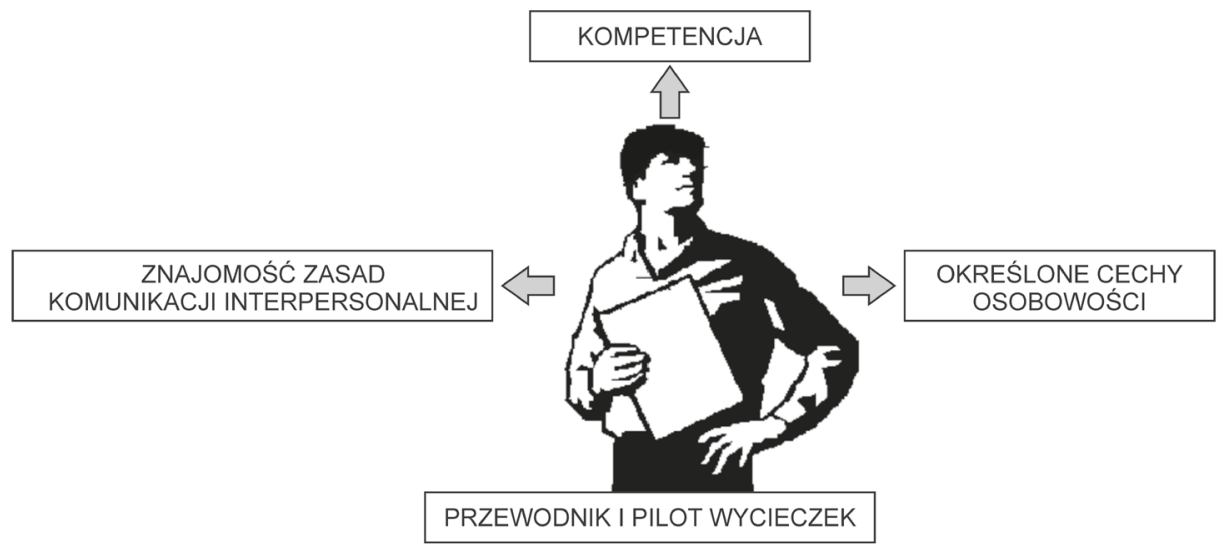

Rysunek 1. Cechy i umiejętności przewodnika/ pilota wycieczek Źródło: opracowanie własne na podstawie Meyer (2006, s. 162-164) 
Znajomość zasad komunikacji interpersonalnej nabiera istotnego znaczenia podczas bezpośredniego kontaktu pilota i przewodnika z turystami. Przewodnik lub pilot, porozumiewając się z turystami, wykorzystuje zarówno komunikację werbalną jak i niewerbalną. Komunikacja werbalna polega na przekazywaniu intencji, myśli i uczuć dzięki słowom, które przewodnik bądź pilot wycieczek wypowiada. Natomiast komunikacja niewerbalna polega na przekazywaniu informacji bez użycia słów. Ważną rolę w tym przypadku odgrywa kontakt wzrokowy, mimika, gestykulacja i postawa ciała, przestrzeń oraz odległość między mówcą i słuchaczem. Komunikacja niewerbalna jest dobrym sposobem wyrażania emocji. W pracy pilota wycieczek i przewodnika obie formy komunikowania są ważne. Sposób, w jaki sformułowany i przekazany zostaje komunikat, ma decydujące znaczenie dla właściwego odbioru informacji. Istotne jest, aby komunikat dotarł do każdego uczestnika imprezy turystycznej w tym samym czasie, a przekazywane informacje były jasne, zrozumiałe i jednoznaczne (Thomson, 1998).

Do cech osobowości preferowanych u pilota lub przewodnika zaliczyć należy: sumienność, otwartość na nowe doświadczenia, ciągłą potrzebę dokształcania i wzbogacania osobowości, zdolność szybkiego oraz łatwego nawiązywania kontaktów z turystami, a także umiejętność ich wysłuchania i zrozumienia (Meyer, 2006).

\section{Metody andragogiki możliwe do zastosowania w krajoznawstwie turystycznym}

Metody andragogiki są pewnym sposobem badania, drogą dochodzenia do prawdy. Powodują one, że przewodnik świadomie wykonuje zespół czynności wywołujących pozytywne zmiany w osobowości dorosłych turystów. Ponadto stają się one skuteczne w momencie, gdy są właściwie ze sobą łączone oraz kiedy wpływają na poznawcza, emocjonalną i praktyczną aktywność dorosłych. To rzecz niezbędna do badania rzeczywistości i oddziaływania na nią. $W$ turystyce traktowanie wszystkich metod kształcenia dorosłych jako całość pozwala zrozumieć, że stanowią one dynamiczny proces kształtowania człowieka, polegający na nieustannym wyborze treści i sposobów działania przewodnika i turystów. Sprawia to również, że proces kształcenia jest chętnie realizowany przez turystów i przynosi im satysfakcję (Okoń, 1995).

Pytania o sposób postępowania w praktyce, dobór stosowanych środków oraz o proces nauczania dorosłych, który pozwoli osiągnąć zamierzone 
wyniki, prowadzą do istotnej kwestii metod nauczania stosowanych w andragogice. Zdaniem Urbańczyka (1973), metoda to pewien sposób lub droga prowadząca do osiągnięcia przez jednostkę pewnego celu. Zaproponował on podział metod znajdujących zastosowanie w andragogice (rys. 2).

METODY ANDRAGOGIKI

\begin{tabular}{|c|c|c|c|c|}
\hline METODY PODAJACE & $\begin{array}{l}\text { METODY OPIERAJACE SIE NA WIEDZY } \\
\text { LUB DOŚWIADCZENIU DOROS } Ł C H\end{array}$ & \multicolumn{3}{|c|}{$\begin{array}{l}\text { METODY STOSOWANE, GDY ŻRÓDŁEM WIEDZY } \\
\text { SA PRZEDMIOTY I ZJAWISKA ZEWNĘTRZNE }\end{array}$} \\
\hline OPOWIADANIE & POGADANKA & OBSERWACJA & & $\begin{array}{c}\text { METODA } \\
\text { EKSPERYMFNT }\end{array}$ \\
\hline WYKŁAD & DYSKUSJA & INSCENIZACJA & POKAZ & \\
\hline GAWĘDA & ĆWICZENIA & \multicolumn{2}{|c|}{ PRACA Z KSIAŻKA } & LABORATORYJNA \\
\hline
\end{tabular}

Rysunek 2. Podział metod andragogiki według Urbańczyka Źródło: opracowanie własne na podstawie Urbańczyk (1973)

W kształceniu ludzi dorosłych rola nauczyciela jest mniejsza i sprowadza się do doradztwa oraz informowania na temat literatury i metod pracy. Mimo to, wskazówki nauczyciela są nie tylko mile widziane przez dorosłych, ale również niezbędne w podejmowanym przez nich procesie samokształcenia oraz samodzielnego poznawania świata. Należy przy tym pamiętać, że w przypadku turystyki krajoznawczej rolę tradycyjnego nauczyciela pełni przewodnik czy też pilot wycieczek.

W procesie kształcenia dorosłych charakterystyczną cechą metod podających jest to, że opiekun przekazuje słuchaczom określone wiadomości. Metoda wykładowa w przypadku turystyki krajoznawczej polega na bezpośrednim i pośrednim przekazywaniu informacji uczestnikom danej wycieczki. Aktywne uczestniczenie w wykładzie wymaga od dorosłych znacznego wysiłku, dlatego też przewodnik dzięki odpowiedniej narracji wywołuje pewne uczucia i ciekawość turystów oraz wzmacnia ich uwagę. Przewodnik musi mieć perfekcyjnie opanowaną sztukę wykładania i być przygotowany nie tylko pod względem merytorycznym. Powinien prowadzić wykład w sposób logiczny z uwzględnieniem myśli podstawowych i głównej tezy, której słuszność pragnie udowodnić. By prelekcja zainteresowała każdego uczestnika, przewodnik powinien posługiwać się takimi zwrotami, terminami i wyrażeniami, które są wszystkim znane. Prawidłowy przebieg wykładu zależy od dostosowania treści do poziomu słuchaczy, ożywienia pogadanki środkami poglądowymi, utrzymania uwagi słuchaczy. Metoda ta sprowadza się zatem do narracji problemowo-hipotetycznej i wprowadzana jest, aby turyści jak najwięcej zapamiętali i zrozumieli podczas zwiedzania (Półturzycki, 1991). 
Dzięki metodzie polegającej na opowiadaniu dostarcza się osobom dorosłym wiadomości w postaci narracyjnej. Oznacza to podawanie faktów zgodnie z ich następstwem czasowym, uwzględniając przy tym związki przyczynowe, jakie między nimi zachodzą. Metoda opowiadania może zostać zastosowana $\mathrm{w}$ przypadku, gdy temat nauczania obejmuje jakąś fabułę. Często zachodzi potrzeba wzbogacenia opowiadania elementami opisu, który jest najprostszym sposobem zapoznania turystów z nieznanymi im osobami, rzeczami, zjawiskami przyrody, wydarzeniami historycznymi. Właściwe opowiadanie musi być żywe, zwarte, obrazowe, pobudzać uwagę turystów oraz trzymać ich w napięciu. Podczas wycieczki przewodnik musi dbać o zwięzłą konstrukcję zdań, posługiwanie się zrozumiałym dla turystów językiem oraz podkreślać sprawy istotne. Opowiadanie podobnie jak wykład można wzbogacić ilustracjami, fotografiami lub osobistym doświadczeniem przewodnika (Okoń, 1995).

W przypadku gawędy zauważa się dużą swobodę traktowania treści. Jest to bardzo przystępna metoda, ponieważ przewodnik winien ubarwiać przekaz różnymi przykładami, anegdotami, dykteryjkami, co w innych metodach raczej nie powinno mieć miejsca. Wprowadza dzięki temu odpowiednią atmosferę - wesołą lub poważną w zależności od poruszanego tematu i postawionego zadania. Wszystko to wpływa na wzrost zainteresowania ze strony słuchaczy (Urbańczyk, 1973).

W praktyce wyznaczenie dokładnej granicy między tymi trzema metodami nie jest rzeczą łatwą, co potwierdzają umiejętności przewodnika, który często nieświadomie przechodzi od jednej z nich do drugiej - w zależności od rodzaju treści, które pragnie przekazać turystom. Natomiast wspólną cechą tych metod jest monolog prelegenta, dlatego powinien on starać się podawać wiadomości w sposób zrozumiały dla każdego. Stosowanie metod podających ukazuje fachowość przewodnika lub pilota, polegającą na rozbudzaniu w dorosłych pozytywnych uczuć, odwagi, entuzjazmu, zainteresowania oraz zapału do dalszego rozwoju, jak również kształtowania właściwej postawy wobec życia i ludzi.

Metody opierające się na wiedzy i doświadczeniu dorosłych stosowane sa, gdy przewodnik pragnie odwołać się do dotychczasowej wiedzy człowieka oraz pogłębić ja, rozszerzyć i utrwalić. Pogadanka jest metodą przynoszącą efekt, gdyż przypomina żywa, codzienną rozmowę, w której przewodnik występuje w roli bezpośredniego współrozmówcy, wprowadzającego turystów w świat poznania - konfrontuje ich z pytaniami oraz wzbudza ciekawość świata. Metoda pogadanki dzielona jest na część: wstępna, przedstawiającą nowe wiadomości oraz utrwalającą. Pogadanka wstępna ma wytworzyć $\mathrm{w}$ turystach stan gotowości do poznania 
nowych rzeczy i zjawisk, pomaga w aktualizacji doświadczeń turystów, przypomina informacje niezbędne do zrozumienia nowych zagadnień. Jej celem jest przygotowanie grupy turystów do nowej pracy, a więc ustalenie tematu i celu wycieczki oraz przydzielenie zadań poszczególnym osobom, omówienie metod pracy i sposobu jej zakończenia. Pogadanka przedstawiająca nowe wiadomości ma formę rozmowy przewodnika $\mathrm{z}$ turystami. W czasie tej rozmowy przewodnik dąży do takiego zaktywizowania turystów, aby nowe treści, które im przekazuje, zostały przez wszystkich uczestników zrozumiane, powiązane z własnym doświadczeniem oraz zapamiętane. Pogadanka utrwalająca to uzupełnianie doświadczeń, przyswajanie nowych informacji i wiązanie ich z poprzednio nabytymi - to wnioskowanie i sprawdzanie oraz tłumaczenie i dowodzenie (Okoń, 1995).

Metoda pogadanki związana jest $\mathrm{z}$ zadawaniem pytań. Zatem $\mathrm{w}$ trakcie zwiedzania przewodnik często zadaje turystom proste lub nieco trudniejsze pytania, zakładając, że znają oni prawidłowe odpowiedzi dzięki dotychczasowej wiedzy i doświadczeniom. Pytania zadawane przez przewodnika lub pilota wycieczek mają również na celu skłonienie dorosłych do głębszego zrozumienia swojej wiedzy oraz wysnuwania wniosków, mających stać się podstawą do zaistnienia i przyswojenia nowych informacji. Pogadankę należy stosować z poczuciem taktu, ponieważ niedopuszczalne jest kompromitowanie dorosłych, gdy nie potrafią na pytanie odpowiedzieć lub podają odpowiedź błędną (Urbańczyk, 1973).

Turyści aktywnie uczestniczą w szukaniu odpowiedzi na pytania i rozwiązywaniu zagadnień poruszanych $\mathrm{w}$ toku dyskusji z przewodnikiem, korzystając równocześnie ze wspólnych dociekań, rozważań i wniosków. Celem polemiki jest rozszerzenie oraz pogłębienie wiadomości turystów na określony temat. Taka wymiana myśli wpływa na poglądy, przekonania i postawy zwiedzających. Uczy dorosłych poprawnego myślenia, właściwego odnoszenia się do osób mających inne poglądy i zajmujących odmienne stanowisko. Przewodnikowi metoda ta umożliwia dokładniejsze poznanie turystów i tym samym daje mu możliwość wpływania na ich postawy oraz przekonania. Najbardziej kształcąca jest rozmowa o charakterze problemowym, w której uczestnicy wycieczki świadomie i zespołowo starają się rozwiązać poruszone zagadnienie, wykorzystując do tego posiadaną wiedzę i doświadczenie (Półturzycki, 1991).

Metoda dyskusji charakteryzuje się tym, że mówca porusza pewne zagadnienie i zachęca uczestników do swobodnej wymiany poglądów, dbając przy tym o porządek podczas przebiegu rozmowy. Głos należy zwłaszcza do turystów, którzy zainteresowani sformułowanym przez 
przewodnika lub pilota wycieczek zagadnieniem zdobywają się na znaczny wysiłek umysłowy, by odnaleźć prawidłowe rozwiązanie. Za sprawą tej metody dochodzi do aktywizacji umysłowej turystów, co potwierdza szczególne wartości kształcące płynące z prowadzenia dysputy.

Metoda ćwiczeń ma za zadanie skłonić uczestników wycieczki krajoznawczej do wielokrotnego wykonywania określonych czynności. Celem metody jest pomoc w nabywaniu przez turystów coraz wyższej sprawności zarówno w działaniach umysłowych, jak i praktycznych. Służy również przekształcaniu zdobytych już przez człowieka informacji w umiejętności. Im lepiej zostaną przyswojone wiadomości teoretyczne, tym szybciej i sprawniej przebiegać będzie realizacja ćwiczeń (Okoń, 1995).

Źródłem wiedzy dorosłych mogą być również przedmioty i zjawiska zewnętrznego świata. Przewodnik może więc wykorzystywać je jako środki służące do ilustracji swoich wywodów. Wśród metod zdobywania wiedzy wyróżniamy: obserwację, pokaz, inscenizację, pracę z książka, eksperyment, metodę laboratoryjną.

Samodzielne kształcenie się oznacza, że turysta jest niezależny. Sośnicki podkreśla, iż samodzielność dorosłych łączy się z ich aktywnością umysłową lub spontanicznością. Praca samodzielna charakteryzuje się tym, że jej koncepcja i wykonanie są świadome, jej przebieg i kontrola w celu doskonalenia są również kierowane oraz wykonywane z rozmysłem. Samodzielność turysty w trakcie wyjazdu krajoznawczego wyraża się w tym, że sam określa cele i zadania dla siebie, ustala przebieg oraz zakres własnego kształcenia. Sprawdza i kontroluje on także swoją pracę oraz udoskonala własne działania (Sośnicki, 1959).

Obserwacja jest ważną metodą zdobywania informacji o otaczającej nas rzeczywistości, gdyż umożliwia jej poznanie, analizę i ocenę. Ma szerokie zastosowanie i towarzyszy innym metodom kształcenia dorosłych, odpowiada pokazowi oraz znajduje zastosowanie w trakcie wykorzystywania przez przewodnika środków dydaktycznych, które konkretyzują część słowną wykładu lub pogadanki. Dorosły turysta powinien świadomie i celowo doskonalić obserwację poprzez określenie przedmiotu, celu i metody obserwowania. W procesie kształcenia dorosłych należy nieustannie nawiązywać do metody obserwacji, doskonalić ją, wzbogacać i unowocześniać (Półturzycki, 1991).

Obserwacja to aktywne ukierunkowanie spostrzeżenia oraz główny środek, za pomocą którego dorośli odbierają i kształtują swoje pojęcie o danym środowisku i jego elementach składowych. Rola mentora, w trakcie korzystania z metody obserwacji, sprowadza się do zapowiedzi oraz 
zwrócenia uwagi na rzeczy lub zjawiska, które szczególnie warto i powinno się zaobserwować. Poruszenie przez przewodnika zagadnienia, problemu czy też pytania przed rozpoczęciem obserwacji nadaje jej kierunek oraz zwiększa szansę, że turyści zauważą cechy najważniejsze z punktu widzenia celu obserwacji. Tak więc obserwacja daje zamierzone efekty, gdy przyświeca jej określony cel poznawczy - w formie zagadnienia, które trzeba rozwiązać lub pytania, na które należy odpowiedzieć. Dlatego ważną rolę odgrywa ciągłe wdrażanie dorosłych w obserwację, wyrabianie w nich spostrzegawczości, a także umiejętności wszechstronnego oglądania i analizowania napotkanych przedmiotów i zjawisk (Kruczek, Kurek, Nowacki, 2012).

Pokaz filmu albo odtworzenie nagrania łączy się często $z$ innymi metodami, choćby z metodą wykładową za pomocą której prelegent wprowadza dorosłych $\mathrm{w}$ jakieś zagadnienie, a następnie dzięki filmowi lub nagraniu daje im wskazówki, na co należy zwrócić uwagę. Jednak najważniejszym celem pokazu jest wytworzenie $\mathrm{w}$ umyśle dorosłych prawdziwego modelu demonstrowanej czynności, co ułatwia późniejsze samodzielne wykonywanie tych samych lub podobnych praktyk. Pokaz filmu ma cel poznawczy - dzięki niemu przewodnik może unaocznić turystom istotne fakty, procesy, zjawiska, które mogą mieć miejsce w trakcie zwiedzania danego miejsca czy obiektu. Po obejrzeniu filmu często wprowadza się dyskusję jako metodę, która pozwala dorosłym na wypowiedzenie swych spostrzeżeń i wniosków. Podobnie dzieje się w przypadku inscenizacji, która jest grą spełniającą bardzo ważna, oczyszczającą i twórczą funkcję wśród dorosłych. Metoda ta jest doskonałym sposobem przedstawienia i ponownego przeżycia różnych sytuacji życiowych, stwarzających jakieś trudności oraz problemy. Pozwala na obiektywne rozeznanie oraz zrozumienie danej sytuacji bądź problemu. Umożliwia dostrzeżenie różnych możliwości rozwiązań, jak również pobudza aktywność osób dorosłych (Wójcik, 2000).

Praca z książką w przypadku kształcenia dorosłych odgrywa istotną rolę. W rzeczywistości obejmuje ona kilka metod szczegółowych, takich jak: czytanie ze zrozumieniem, tworzenie planu przeanalizowanego tekstu, jego streszczenie, opracowanie referatów. Praca z książką to samodzielne korzystanie z tekstów, które stają się źródłem nagromadzonych wiadomości. Jest to metoda skłaniająca do samokształcenia oraz w dużym stopniu aktywizująca dorosłych, ukazująca, że źródłem wiedzy dorosłych może być nie tylko obserwacja i żywe słowo mentora, lecz także słowo pisane. Dorośli powinni umiejętnie korzystać z tej metody, tzn. wykazywać się zdolnością wyodrębniania najważniejszych informacji, sporządzania 
notatek niezbędnych do zapamiętania oraz umiejętnością samodzielnej analizy i krytycyzmu przeczytanych treści (Okoń, 1995).

Metoda eksperymentu jest doskonałym sposobem potwierdzenia poznanych tez. Należy jednak pamiętać, że eksperymentowanie wymaga odpowiedniego przygotowania teoretycznego. Natomiast metoda laboratoryjna odznacza się dużymi wartościami kształcącymi. To dzięki niej istnieje możliwość zapoznania dorosłych z metodami stosowanymi w nauce, rozbudzenia zainteresowań badawczych oraz spostrzegawczości (Urbańczyk, 1973).

Omawiając metody andragogiki, warto wspomnieć o metodach waloryzacyjnych. Według Okonia (1995, s. 269):

[...] tę grupę metod znamionuje wielkie bogactwo odmian, zależnie bowiem od rodzaju wartości zmienia się sposób ich eksponowania i wpływania na takie składniki osobowości jak uczucia, a szczególnie uczucia wyższe, przekonania światopoglądowe, postawy, system wartości i charakter. Inaczej eksponuje się wartości moralne, których nośnikiem jest dzieło literackie, a inaczej, gdy jest nim biografia konkretnego człowieka lub jakiś czyn ludzki. Jeszcze inaczej dzieje się to, gdy eksponujemy wartości muzyczne czy plastyczne, a wśród tych drugich na przykład obraz, film czy dzieła architektury. Różnice w tych i innych przypadkach są bardzo duże, toteż nie sprzyjały one ukształtowaniu jakichkolwiek klasyfikacji metod eksponujących. Można było natomiast dokonać ich podziału na metody impresyjne i ekspresyjne.

Metody impresyjne służą do organizowania uczestnictwa dorosłych w eksponowanych wartościach społecznych, moralnych, naukowych i estetycznych. Celem jest nakłonienie człowieka do zdobycia wiadomości na temat eksponowanego dzieła i jego twórcy, aby wzbudzić w odbiorcy chęć oceniania tego dzieła. Natomiast metoda ekspresyjna stwarza sytuacje, w których dorośli sami wytwarzają czy też odtwarzają dane wartości, wyrażając $w$ ten sposób siebie. Pojawiająca się w tym przypadku ocena ma niebywałe znaczenie, ponieważ jest częścią przeżyć, jakich doznał człowiek (Okoń, 1995).

Przewodnik lub pilot wycieczek, wybierając daną metodę, ma na uwadze cel, który sobie w pracy stawia. Dlatego gdy chce upowszechnić pewne wiadomości, posługuje się metodą wykładową. Natomiast gdy zamierza rozwijać zdolności umysłowe dorosłych, większy nacisk kładzie na zastosowanie metody pogadankowej, dyskusji czy pracy własnej danej jednostki. Do wypracowywania umiejętności wykorzystuje z kolei metodę ćwiczenia. Wybór metody zależy także od tematu, który ma być przedmiotem rozważania oraz, co najistotniejsze, od poziomu przygotowania i zaangażowania dorosłych. 
W dzisiejszych czasach ogromne znaczenie ma nauczanie problemowe, które angażuje dorosłych do pracy nad problemem, natomiast przewodnikowi i pilotowi wycieczki stwarza możliwość stosowania powyżej wymienionych metod, mających charakter aktywizujący i interakcyjny. Metody te służą zatem nie tylko rozbudzaniu zainteresowań, aktywności dorosłych, ale również mają przyczyniać się do odprężenia i rozluźnienia odbiorców. Przede wszystkim nie można zapomnieć również o oddziaływaniu powyższych metod na uczucia, przeżycia czy wrażenia dorosłych. Należy pamiętać, aby dobierać takie metody, które najtrafniej odpowiadają celowi spotkania - powinny one rozbudzać pragnienia ludzi dorosłych. Zastosowanie właściwej metody sprawia, że dorośli w większym stopniu wykazują własną aktywność w danej dziedzinie. Metody powinny stać się pomocą w przekazywaniu i rozwijaniu treści. Dlatego istotną rzeczą jest dokładne przemyślenie i staranne przygotowanie niezbędnych pomocy do przeprowadzenia stosownych metod aktywizujących i interakcyjnych (Wójcik, 2000).

\section{Podsumowanie}

Urbańczyk (1973) uważa, że najtrafniejszym sposobem podziału metod kształcenia jest ich klasyfikacja według źródła wiedzy, na której opiera się proces nauczania. Źródłem tym może być przewodnik, własne doświadczenie oraz dotychczasowa wiedza turysty, a także przedmioty i zjawiska zewnętrznego świata. Dostrzec można, że gdy jakieś zagadnienie jest znane turystom, przewodnik może odwołać się do posiadanej przez nich wiedzy i pogłębić ją poprzez zastosowanie metody pogadanki, dyskusji czy ćwiczenia w celu kształcenia nowej umiejętności. Okoń, w książce Wprowadzenie do dydaktyki ogólnej (1995), wyodrębnia cztery grupy metod kształcenia, m.in.: metody asymilacji wiedzy, metody samodzielnego dochodzenia do wiedzy, metody waloryzacyjne oraz metody praktyczne. Podkreśla on, że praca z wykorzystaniem każdej z tych metod aktywizuje zarówno przewodnika, jaki i turystów. Natomiast Półturzycki ze względu na złożoność metod kształcenia dorosłych dokonuje ich podziału na metody proste i kompleksowe. Do metod prostych zalicza wykład, dyskusję, pokaz czynności oraz pogadankę. Zaś wśród metod kompleksowych wyróżnia metodę nauczania praktycznego i metodę problemową. Kupisiewicz w Podstawach dydaktyki ogólnej (1976) wyróżnia metody oparte na słowie, do których zalicza pogadankę, wykład, pracę z książką oraz dyskusję. Wymienia również metodę opierającą się na obserwacji i pomiarze, oraz metodę nauczania problemowego. 
W literaturze dotyczącej andragogiki można spotkać się z różnorodnym podziałem metod kształcenia dorosłych (rys. 3).

W edukowaniu dorosłych istotną rolę odgrywa rozpowszechniona w dzisiejszych czasach metoda wizualizacji. Niewątpliwie najważniejszym nośnikiem audiowizualnym jest przewodnik lub pilot wycieczek, który doskonale posługuje się nie tylko językiem werbalnym, ale przede wszystkim mową ciała. Wizualizacja to dobry sposób ćwiczenia wyobraźni dorosłych, pomaga w zapamiętywaniu oraz szybszym kojarzeniu różnych faktów, wyrazów, informacji i zależności między nimi. Dzięki wizualizacji w większym stopniu można zwrócić uwagę na przedstawiony

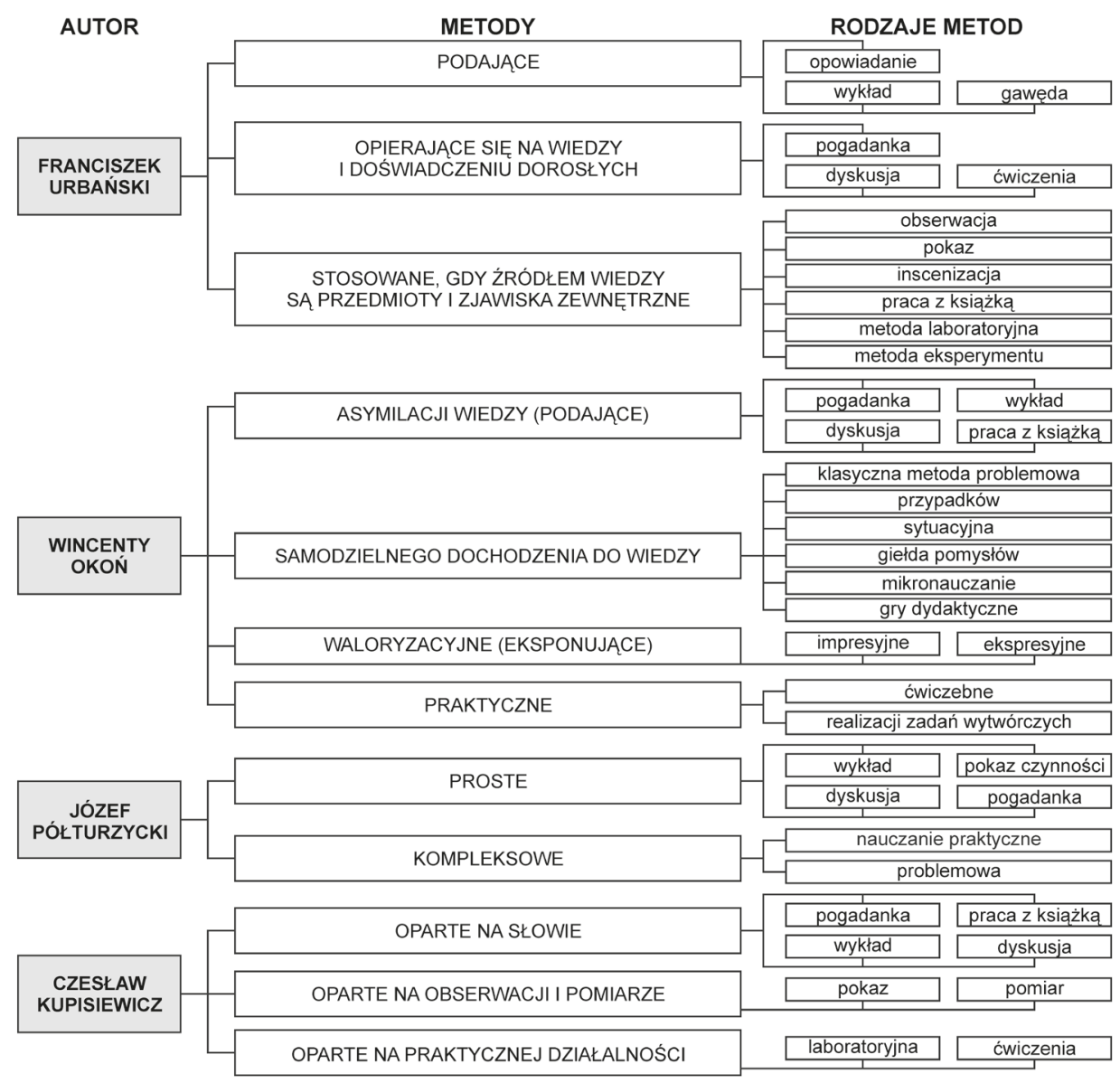

Rysunek 3. Podział metod kształcenia dorosłych według wybranych autorów Źródło: opracowanie własne na podstawie: Urbańczyk (1973), Okoń (1995), Półturzycki (1991), Kupisiewicz (1976) 
przedmiot lub poruszony temat, zwiększając w ten sposób zainteresowanie osób dorosłych oraz angażując ich emocje. Zaletą wizualizacji jest również to, że staje się ona ułatwieniem $\mathrm{w}$ zapamiętywaniu nowych informacji, a także ich przetwarzaniu i organizowaniu w jedną całość. Metoda ta zyskuje uznanie wśród wielu dorosłych, ponieważ jest bardziej atrakcyjna i przyjemniejsza od tradycyjnych sposobów nauki. Należy jednak pamiętać, że metoda wizualizacji powinna być stosowana z rozsądkiem, gdyż użycie jej w sposób niewłaściwy może powodować rozproszenie odbiorców, zmniejszenie ich wysiłku intelektualnego oraz zmniejszenie efektywności kształcenia się. Dlatego tak ważne jest właściwe i umiejętne jej zastosowanie (Religa, Szpilska, 2006).

Ważnym zadaniem andragogiki jest badanie uniwersalnych prawidłowości procesu kształcenia, samokształcenia, jak również samowychowania osób dorosłych. W edukacji dorosłych rozpatruje się warunki oraz możliwości tworzenia zintegrowanej wiedzy na temat ludzi dorosłych, wykorzystanej do analizy rozwoju dorosłych oraz programowania celów i treści ułatwiających wychowanie zgodnie z potrzebami życia społecznego. Wskazuje ona na prawidłowości kształtowania podmiotowości danej jednostki w pracy, życiu społecznym i rodzinnym oraz w czasie wolnym. Andragogika wyznacza możliwości takiego kształcenia, wychowania i samokształcenia dorosłych, które bez wątpienia będą sprzyjały integracji osobowości poszczególnych jednostek oraz ułatwiały ich działanie w pracy zawodowej, działalności społecznej itp.

Problematyka metod kształcenia i wychowania w andragogice to zagadnienie wymagające nowego ujęcia. Dorośli są bowiem na ogół krytyczni, sceptyczni, nieufni oraz pełni obaw. Z drugiej zaś strony cechuje ich pragnienie zdobywania wiedzy oraz chęć zachowania własnej indywidualności. Dlatego w przypadku andragogiki należy pamiętać, że metoda kojarzona jest ze sposobem oddziaływania wychowawczego, którego skutków nie można do końca przewidzieć. Głównym zadaniem wspomnianych metod jest pobudzenie u dorosłych pragnienia kształtowania w swojej osobowości tych cech, które staną się dla nich ułatwieniem w prawidłowym funkcjonowaniu oraz rozumieniu otaczającej rzeczywistości (Pięta, 2004).

\section{Bibliografia}

Gołembski, G. (red.) (2003). Vademecum pilota grup turystycznych. Poznań: Wydawnictwo Akademii Ekonomicznej w Poznaniu.

Kaczor, E. (2001). Metodyka organizowania, programowania oraz technika prowadzenia wycieczek. Lider, 7 (8), 14-15. 
Kruczek, Z. (red.) (2014). Kompendium pilota wycieczek. Kraków: Proksenia.

Kruczek, Z., Kurek, A., Nowacki, M. (2012). Krajoznawstwo. Zarys teorii i metodyki. Kraków: Proksenia.

Kupisiewicz, C. (1976). Podstawy dydaktyki ogólnej. Warszawa: Państwowe Wydawnictwo Naukowe.

Meyer, B. (red.) (2006). Obstuga ruchu turystycznego. Warszawa: Wydawnictwo Naukowe PWN.

Okoń, W. (1995). Wprowadzenie do dydaktyki ogólnej. Warszawa: „Żak”.

Pięta, J. (2004). Pedagogika czasu wolnego. Warszawa: Wyższa Szkoła Ekonomiczna.

Półturzycki, J. (1991). Dydaktyka dorosłych. Warszawa: Wydawnictwa Szkolne i Pedagogiczne.

Przecławski, K. (1996). Człowiek a turystyka. Zarys socjologii turystyki. Kraków: Albis.

Religa, J., Szpilska, M. (2006). Metody wizualizacji w ksztatceniu dorostych. Edukacja Ustawiczna Dorostych, 2, 68-72.

Sośnicki, K. (1959). Dydaktyka ogólna. Wrocław: Zakład Narodowy im. Ossolińskich.

Thomson, P. (1998). Sposoby komunikacji interpersonalnej. Poznań: Zysk i S-ka.

Turos, L. (2004). Andragogika ogólna. Warszawa: Żak.

Urbańczyk, F. (1973). Dydaktyka dorosłych. Wrocław: Zakład Narodowy im. Ossolińskich.

Wójcik, E. (2000). Metody aktywizujace w pedagogice grup. Kraków: Rubikon.

Wujek, T. (red.) (2006). Wprowadzenie do andragogiki. Radom: Instytut Technologii Eksploatacji.

Zaorska, Z., Kędzior-Niczyporuk, E. (2000). Aktywność jako wartość - turystyka w starszym wieku. Grupa i Zabawa, 2, 2-6.

\title{
MOŻLIWOŚCI WYKORZYSTANIA METOD ANDRAGOGIKI W KRAJOZNAWSTWIE TURYSTYCZNYM
}

\begin{abstract}
Abstrakt: Coraz więcej osób starszych bierze udział w turystyce poznawczej, co sprawia, że organizatorzy takich wyjazdów muszą dostosować sposób prezentacji walorów turystycznych do tej grupy odbiorców. Celem artykułu jest przeniesienie doświadczeń związanych z kształceniem dorosłych na grunt krajoznawstwa turystycznego. Całość została podzielona na cztery części, w których zgodnie z zasadą od ogółu do szczegółu, zajęto się andragogiką i jej metodami, modelem właściwego zachowania przewodnika w pracy z osobami dorosłymi oraz selekcją metod właściwych dla dorosłych turystów. Artykuł kończy podsumowanie, w którym jednoznacznie wskazuje się na potrzebę wykorzystania andragogiki w krajoznawstwie.
\end{abstract}

Słowa kluczowe: krajoznawstwo, andragogika, turystyka.

\section{OPPORTUNITIES FOR USING THE METHODS OF ANDRAGOGY IN SIGHTSEEING}

\begin{abstract}
An increasing percentage of older people participating in cognitive tourism forces the organizers of such trips to adapt their way of presenting what is of tourist value. The article is an attempt to transfer experience related to adult education to the field of tourism. It is divided into four parts: the first describes andragogy and its methods, the next focuses on the model of behavior for a guide while working with adults, followed by one describing the selection methods appropriate for this group of tourists. The article ends with an epilogue that clearly indicates the need to use andragogy in preparing sightseeing.
\end{abstract}

Keywords: sightseeing, andragogy, tourism. 